\title{
TRABALHO FAMILIAR: UMA CATEGORIA ESQUECIDA DE ANÁLISE
}

\author{
MARIA IGNEZ S. PAULILO \\ Universidade Federal de Santa Catarina
}
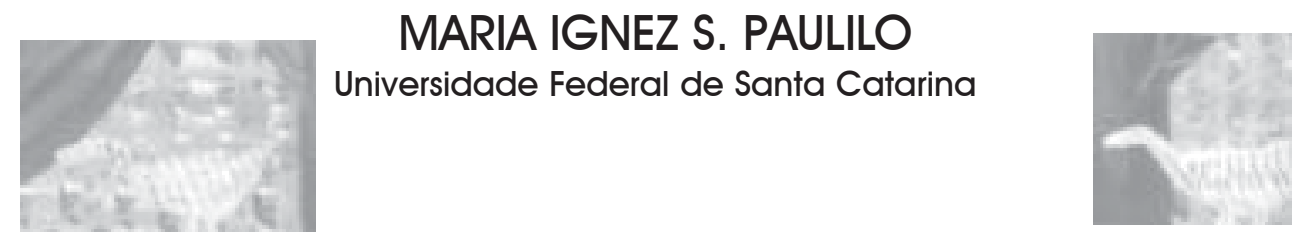

Resumo: A influência do marxismo na Sociologia do trabalho e no feminismo foi e ainda é muito grande, o que trouxe uma ênfase nos estudos sobre o operariado. Com isso, o campesinato tornou-se um tema de difícil articulação dentro do marxismo e do feminismo. Havia uma crença generalizada de que liberação das mulheres passaria necessariamente por sua independência financeira, fruto da inserção individual no mercado de trabalho. Como 'encaixar' aí as mulheres em regime de trabalho familiar? Elas não foram bem 'encaixadas', havendo com freqüência um 'viés urbano' perpassando as análises do trabalho feminino no campo. O surgimento de vários movimentos de mulheres agricultoras no Brasil colocou em cheque a visão corrente de 'vítimas' que se tinha sobre elas, na medida em que estão se impondo como 'atoras'. Neste momento, porém, os movimentos feministas estão mais voltados para questões de reconhecimento, de identidade, que de redistribuição de renda, propriedades e, o que nos interessa mais, terra. Nosso objetivo neste trabalho é desvelar os preconceitos imbricados na análise do campesinato e trazer de volta questões sobre a condição econômica desigual das mulheres envolvidas na agricultura familiar, cujo acesso à terra se faz quase unicamente pelo casamento. O direito de tomar decisóes sobre a própria vida pode ser desvinculado da obtenção de um salário individual, mas não do acesso a uma renda própria. Palavras-chave: movimentos sociais rurais, gênero, agricultura familiar, feminismo.

A influência do marxismo no pensamento feminista é inegável, principalmente quando a temática é trabalho. No Brasil, essa influência é nítida, tanto no meio acadêmico quanto nos movimentos sociais, o que se torna mais compreensível quando nos lembramos que o feminismo começa a se tornar presente em terras brasileiras em plena ditadura militar e estando em vigência um modelo econômico fortemente concentrador de renda. Se, por um lado, a pressão econômica levava a uma ênfase nas questões de classe, a falta de liberdade política fazia com que a contestação procurasse espaços não proibidos para se manifestar, e os movimentos de mulheres foram um desses espaços. Se, no campo da militância, foram os espaços feministas que abrigaram muitas das bandeiras do movimento trabalhista, no meio acadêmico houve como que uma inversão, e foi a Sociologia do Trabalho que abrigou as discussões feministas. Alice Rangel de Paiva Abreu' nos fala sobre isso ao relatar como as discussões feministas catalisadas pelo já histórico seminário "A mulher na

Copyright (C) 2004 by Revista Estudos Feministas

1 ABREU, 1985. 
força de trabalho na América Latina", ocorrido em 1978 na cidade do Rio de Janeiro, infiltraram-se nos encontros da Associação Nacional de Pós-Graduação e Pesquisa em Ciências Sociais, através do grupo que discutia processos de trabalho e reivindicações sociais.

O campesinato ${ }^{2}$ sempre foi um tema de difícil articulação dentro do marxismo, e isso se refletiu nos estudos feministas. Havia uma crença generalizada de que a liberação das mulheres passaria necessariamente por sua independência financeira, fruto da inserção no mercado de trabalho. Como 'encaixar' aí as mulheres em regime de trabalho familiar? Nosso objetivo neste artigo é mostrar que elas não foram bem 'encaixadas' e que há um 'viés urbano' perpassando as análises sobre trabalho feminino no campo, viés que se estende inclusive ao entendimento de seus movimentos reivindicativos, seja o Movimento das Mulheres Trabalhadoras Rurais (MMTR), seja o movimento sindical ou, ainda, a luta das mulheres ligadas ao Movimento dos Trabalhadores Rurais Sem Terra (MST).

\section{Campesinato e história}

A coletânea organizada por André L. Chevitarese e recentemente publicada - $O$ campesinato na história ${ }^{3}$ - mostra como é profunda a raiz evolucionista que coloca campo e cidade em um crescendo civilizador. A própria Sociologia traz essa marca, sacramentada desde seus primórdios pela dicotomia 'comunidade/sociedade' (Gemeinschaft) Gesselschaft), criada por Ferdinand Tönnies em 1887, em que o primeiro termo se refere a "fudo que é confiante, íntimo, vivendo exclusivamente junto" e o segundo, "é o que é público; é o mundo" . ${ }^{4}$

A complexidade do pensamento de Tönnies não permite que esses dois pólos sejam excessivamente simplificados. Embora ele se refira à sociedade de maneira um tanto amarga e autores como Herman Schmalenbach ${ }^{5}$ salientem que ele concebe a comunidade como um lugar mais aprazível de se viver, pouco enfatizando os conflitos, não deixa de identificar a sociedade positivamente com valores caros aos pensadores do século XIX. Enquanto a comunidade é vista como o lugar dos afetos mas também da tradição, a sociedade é o lugar dos interesses, mas também da vontade independente. É a sociedade o espaço privilegiado do pensamento e do comportamento racionais, é o espaço do 'indivíduo' e da 'independência', o que nos remete à noção de 'liberdade'. Weber retoma a distinção de Tönnies, dando-lhe a forma de tipo ideal e acentuando a relação entre sociedade e razão. ${ }^{6}$

\footnotetext{
${ }^{2} \mathrm{O}$ uso ou não do termo 'campesinato' para designar agricultores familiares brasileiros sempre foi polêmico. Muitos estudiosos crêem que essa categoria só se aplica a países que tiveram um passado feudal. Outros a reservam para agricultores pouco ligados ao mercado. Nós, neste trabalho, estamos considerando como camponeses os agricultores que trabalham principalmente com mão-de-obra familiar e são considerados pequenos e médios proprietários e produtores, segundo os critérios do INCRA e da FAO para a região em que vivem. Admitimos que, com isso, estamos trabalhando com um falso grau de homogeneização desse grupo, que o conceito de 'agricultor familiar' também não elimina. O termo 'camponês' nos é mais adequado porque, primeiro, nos permite comparar melhor estudos feitos na Europa e no Brasil. Segundo, tem uma conotação política de criação de identidade em momentos de luta (haja vista as Ligas Camponesas), que as militantes do Movimento de Mulheres Trabalhadoras Rurais (MMTR) estudadas neste artigo querem recuperar. Tanto querem recuperar essa identidade que está em processo a mudança do nome do movimento para Movimento de Mulheres Camponesas (MMC). Ressaltamos que não estamos considerando o termo 'agricultura familiar' mais neutro politicamente que o de 'camponês', apenas que ele cria uma identidade menos moldada pelo confronto. Como diz Max WEBER, 1977a, p. 22, "Porque a 'linha de centro' não é, de modo algum, uma verdade mais científica que os ideais dos partidos mais extremos da direita ou da esquerda".

${ }^{3}$ CHEVITARESE, 2002.

${ }^{4}$ TÖNNIES, 1977, p. 107.

${ }^{5}$ SCHMALENBACH, 1977, p. 117.

${ }^{6}$ WEBER, 1977b, p. 33-37.
} 
A noção de comunidade como definindo um lugar de igualdade, integração, tradição e afeto, muito mais do que de hierarquias, conflitos, mudanças e escolhas racionais, firmou-se na Sociologia através dos Estudos de Comunidades inspirados na corrente funcionalista. A ênfase dessa vertente em pequenos grupamentos fez do campesinato um de seus principais objetos de estudo e, assim, ele passou a ser identificado com os valores que compunham a idéia de vida em comunidade e, portanto, como pouco afeito ao comportamento racional. A imagem que as elites produziram dele ao longo da história tem a ver com a valorização que faziam da razão e da emoção. Daí decorriam visões opostas do que seja o camponês, ora representado como um ser puro, quando a emoção falava mais alto, ora como um ser bruto, quando se valorizava a razão.

A influência da oposição 'comunidade/sociedade', criada por Tönnies, foi tão forte nos estudos rurais que é preciso desconstruí-la para que o pensamento crítico avance. Jonathan Murdoch e Andy Pratt, 7 ao falarem sobre os 'estudos de comunidade', dizem que estão presentes neles duas pressuposições: a) as comunidades são espaços que estão fora da influência da modernidade; e b) as forças dessa modernidade estão próximas e ameaçam o futuro dos espaços de vida tradicional. Freqüentemente, o romantismo implícito no desejo de preservar os modos de vida tradicionais permeia essas análises, fazendo com que sejam vistos como contendo a 'essência' de uma determinada cultura ou nação.

Em outro texto de Murdoch, escrito em parceria com outros quatro autores, ${ }^{8}$ a crítica ao conceito de comunidade continua presente. Ao colocarem as questões rurais como centrais para a Sociologia, ressalvam que seus argumentos não sugerem um novo surgimento do termo 'comunidade', nem uma manutenção do que chamam de "rural idyll”, ou seja, uma visão idílica do rural. O que dizem é que essas questões aparecem e reaparecem porque são cruciais, pois se referem a características fundamentais do desenvolvimento capitalista contemporâneo.

A maneira corriqueira como são associados campesinato e tradição faz com que nos esqueçamos de que essa própria associação tem sua história. Como diz Liana Vardi, ${ }^{9}$ a idéia de que os camponeses são repositórios de culturas tradicionais é uma idéia recente, pois até o século XVIII os europeus os viam como uma rematada antítese da cultura. Para os pensadores sociais medievais, eles eram bestiais e servis por natureza. Teodor Shanin ${ }^{10} \mathrm{Cita} O$ historiador francês Jacques Le Goff em uma epígrafe para nos mostrar a dimensão desse preconceito, pois este último transcreveu um trecho da Declinatio Rustica alemã do século XIII que tinha seis declinações para a palavra 'camponês' - "vilão, rústico, ladrão, bandido e saqueador" - e no plural "miseráveis, mendigos, mentirosos, vagabundos, escórias e infiéis".

Vardi, porém, diz que não só de idéias negativas se alimenta o mito camponês. Analisando pinturas e poesias sobre colheitas, ela mostra que no século XVI, por exemplo, quando se dá a independência dos servos com relação às terras senhoriais, não se os representa mais como servis, o que é facilmente compreensível. Além disso, há uma valorização das paisagens pastoris. Já no século XVII, o camponês aparece como uma figura ameaçadora. Enfim, ele aparece tanto como a personificação do bem, quanto a personificação do mal. Na modernidade, como é considerado feio demais para merecer sua representação no que se considera arte, ele é 'embelezado' para isso e suas imagens pouco têm a ver com a realidade; ele deixa de ser de carne e osso e aparece sempre como metáfora.

\footnotetext{
${ }^{7}$ MURDOCH E PRATT, 1993, p. 417.

${ }^{8}$ Terry MARSDEN et al., 1992.

${ }^{9}$ VARDI, 2001.

10 SHANIN, 1980.
} 
Ciro F. Cardoso 11 cita Pierre Vilar para nos mostrar mais de uma face do preconceito. Segundo Vilar, desde o surgimento das cidades, a imagem do camponês sofre uma dupla mitificação, pois convivem lado a lado um desprezo pelo "rústico" e uma imagem romântica do "lavrador" ou do "pastor", ou seja, há um "elogio da aldeia". Para Vilar, esta mesma visão dupla se repete quando se trata de analisar o comportamento político do camponês, que tanto pode ser visto como reacionário, como nele são depositadas grandes esperanças revolucionárias.

A polêmica sobre a capacidade ou não do campesinato de ser uma classe revolucionária é bem conhecida dos sociólogos rurais. A posição do marxismo, ou melhor, as posições dos marxistas sobre essa questão tiveram papel relevante no debate.

\section{Campesinato e marxismo}

Há consenso, entre os pesquisadores, de que, para os marxistas clássicos, a classe revolucionária por excelência era o proletariado. Na obra O 18 Brumário, de Karl Marx, a comparação que ele faz do campesinato a um "saco de batatas", no sentido de que os camponeses estão juntos mas não têm uma ação coletiva, é bastante conhecida e citada. ${ }^{12}$ Mas para alguns estudiosos, como Cardoso, ${ }^{13}$ a esquerda atual ainda continua a vê-los de maneira preconceituosa.

Um dos autores que colocaram bem o dilema dos marxistas diante da persistência do campesinato é Jerzy Tepicht, ${ }^{14}$ dizendo que o modelo de relações de produção capitalista na agricultura, construído por Marx com base na realidade da Inglaterra da época, em que pese seu inegável valor heurístico, não se confirmou historicamente. Nesse modelo havia lugar apenas para três personagens: o proprietário de terras, o arrendatário capitalista e o assalariado agrícola. Segundo autores ingleses como Ruth Gasson e Andrew Errington, ${ }^{15}$ nem mesmo em terras britânicas o campesinato era assim tão pouco importante como Marx considerou. Para eles, embora as referências à agricultura do Reino Unido no século XIX sempre coloquem esse período como dominado pela grande exploração capitalista, havia significativa diversidade no meio rural. O que explica em parte esse viés é o fato de que a agricultura capitalista foi realmente forte nesses anos considerados "the Golden Age of British agriculture", porém essa situação começa a se modificar por volta de 1870 e a relevância da exploração familiar volta a crescer. Outro ponto ressaltado por Gasson e Errington é que a análise marxista tradicional negligenciou a família, porque o futuro desta era visto como fruto de uma marginalização crescente ao processo de produção, à medida que o capitalismo se desenvolvia.

A convicção de que o campesinato estava fadado ao desaparecimento foi reforçada pelos escritos de Wladimir Lênin e Karl Kautsky. Como diz Ricardo Abramovay, ${ }^{16}$ as obras centrais desses autores, ambas publicadas em 1899 - O desenvolvimento do capitalismo na Rússia (Lênin) e A questão agrária (Kautsky) -, devem ser compreendidas levando-se em conta as lutas políticas de que fazem parte e não como continuação ortodoxa da teoria marxista.

\footnotetext{
11 CARDOSO, 2002, p. 22.

12 Para uma crítica dessa postura, ver Ricardo ABRAMOVAY, 1992.

${ }^{13}$ CARDOSO, 2002, p. 27.

14 TEPICHT, 1973.

${ }^{15}$ GASSON E ERRINGTON, 1993, p. 51.

${ }^{16}$ ABRAMOVAY, 1992.

17 WILKINSON, 1986.

${ }^{18}$ Maria Paula ARAÚJO, 2002 , p. 67.
} 
Um dos pontos centrais da obra de Lênin é sua demonstração, com base em estatísticas da época, de que estaria havendo uma diferenciação do campesinato russo em duas direções e apenas $30 \%$ dos antigos camponeses ainda poderiam ser considerados como tais, enquanto que $20 \%$ já seriam burguesia rural e $50 \%$, proletariado. A idéia de "diferenciação camponesa" marcou fortemente os estudos rurais brasileiros, tendo essa expressão designado grupos de trabalho em seminários e congressos. Os dados eram tão óbvios assim? John Wilkinson ${ }^{17}$ contesta e, em um cuidadoso exercício de reinterpretação dos mesmos dados utilizados por Lênin, conclui que o campesinato médio na Rússia representava $60 \%$ dos agricultores.

Lênin, no entanto, uma vez tendo assumido o governo, foi sensível à questão camponesa e passou a ver o campesinato como aliado. Foi no período de lossif Stálin que se deu a violenta socialização das terras na Rússia e o campesinato foi visto como inimigo da revolução. ${ }^{18}$

A ênfase no desaparecimento do campesinato nos países capitalistas, por um lado, e na coletivização da terra nos países onde fosse feita a revolução socialista, por outro, levou a que pouco se teorizasse sobre o trabalho familiar dentro das correntes marxistas e, conseqüentemente, sobre a propriedade familiar. No entanto, segundo dados da Comissão Econômica para a América Latina (CEPAL), a população rural da América Latina ${ }^{19}$ tem se mantido nas últimas décadas em torno de 125 milhões de pessoas e está começando a haver um leve crescimento que se estima continuará por pelo menos mais uma década.

\section{Mulher e propriedade da terra}

Um fato bem conhecido, entre nós, é que o acesso das mulheres à terra é menor que o dos homens no mundo todo. A América Latina e, dentro dela, o Brasil não são exceções. A conquista do direito a esse bem em vários países não significou uma possibilidade concreta de filhas de agricultores partilharem a herança em pé de igualdade com seus irmãos homens.

A exclusão das mulheres de várias formas de direito vem de longa data. Mesmo para ter acesso ao voto, as mulheres tiveram que esperar mais de um século após a Revolução Francesa. Segundo Rachel Sohiet, ${ }^{20}$ o Brasil, em 1932, foi o quarto país do mundo e o segundo da América Latina que possibilitou às mulheres poderem votar e serem votadas. Fez isso depois do Canadá, Estados Unidos e Equador. A igualdade de gênero explícita na Constituição demorou décadas mais. Hoje apenas um, entre os 19 países que formam a América Latina, a República Dominicana, ainda não a tem. Quanto à abolição do poder marital, parte dos países latino-americanos precedeu mesmo a França, berço da revolução que instituiu os direitos individuais. Lá o Código Napoleônico, que começou a ser questionado apenas em 1938, estabelecia o poder do marido sobre os bens da esposa, poder este que tem suas raízes no Direito Romano.

Quanto ao direito à terra por parte das mulheres, ele segue as restrições do direito à propriedade nos países onde não há um direito agrário separado do direito civil, como é o caso do Brasil. Ao falarmos da propriedade da terra, estaremos nos referindo apenas às explorações familiares, em que predomina a forma de trabalho que estamos analisando. Porém, mesmo quando o direito garante a igualdade de gênero, isso não significa que na partilha da propriedade agrícola as filhas herdem como os filhos. Da mesma forma, nos

\footnotetext{
${ }^{19}$ Maria Nieves RICO e Martine DIRVEN, 2003.

${ }^{20}$ SOHIET, 2004.
} 
países onde houve reformas agrárias, as mulheres foram bastante discriminadas. Segundo Carmen Deere e Magdalena Léon, a maior porcentagem de beneficiárias individuais (nãocooperativadas ou em terras coletivas) encontrada em 13 programas de reforma agrária e de colonização latino-americanos foi de 17,2 \% (Bolívia). O Brasil apresentava em 1996 um total de 12,6\%. Para elas, "a mulher foi excluída das reformas agrárias latino-americanas por razões legais, estruturais, ideológicas ou culturais e institucionais". ${ }^{21}$ Com exceção das razões legais, o mesmo se aplica à herança da terra.

Em trabalho anterior, ${ }^{22}$ fizemos referência ao quanto é difícil abordar questões relacionadas à herança junto aos agricultores familiares, sejam maridos, esposas, filhas ou filhos. Reforçam nossa percepção resultados de uma pesquisa realizada na região Sul do Brasil pelo Departamento Sindical de Estudos Rurais (DESER), ${ }^{23}$ que entrevistou 141 jovens e 240 adultos de ambos os sexos. Quando Ihes foi perguntado quais as chances de rapazes e moças herdarem as terras dos pais, $32 \%$ preferiram não responder e, embora $40 \%$ tenham respondido que as chances eram iguais, $51 \%$ não conheciam nenhuma moça que tivesse herdado. ${ }^{24}$

Nas regiões de colonização italiana e alemã dos três estados do Sul do País, há um mesmo padrão a respeito da herança da terra. ${ }^{25}$ Embora esse padrão comporte variações, podemos dizer com segurança que são principalmente os filhos homens que herdam a terra. $O$ acesso das mulheres a esse bem se faz pelo casamento. Aparecem exceções quando não há descendência masculina, quando há uma filha casada que cuida dos pais na velhice, quando os pais possuem muita terra ou, ao contrário, quando a exploração agrícola não tem importância como meio de produção para os herdeiros. Lembremos que nem todos os filhos homens herdam terra quando a propriedade é pequena, porém para eles há mecanismos de compensação que tentam respeitar uma correspondência entre o que foi perdido e o que foi ganho. Os que estudam, sejam homens ou mulheres, não herdam terra porque 'já ganharam o estudo'. Também não a recebem quando saem da casa dos pais e vão trabalhar na cidade, enquanto um ou mais irmão ficam. Quanto às mulheres, recebem um enxoval quando se casam, composto de mais ou menos itens dependendo das posses dos pais. As que não se casam nada recebem. $O$ destino das celibatárias - cuidar dos pais e, depois de sua morte, ficar 'encostada' na casa de uma irmã ou cunhada, ajudando nos afazeres domésticos - não é invejado por ninguém.

Uma vez rompido o tabu de falar sobre assunto tão doloroso, as mulheres entrevistadas, quando sozinhas conosco, mostram-se revoltadas com tal discriminação, dizendo sempre que "trabalharam tanto quanto seus irmãos na terra dos pais" e, por isso, mereceriam herança igual. Elas não apóiam suas reivindicações na idéia de igualdade de gênero, nem no fato de serem filhas legítimas de seus pais, mas no fato de terem trabalhado para manter e mesmo aumentar o patrimônio familiar. ${ }^{26}$

\footnotetext{
${ }^{21}$ DEERE e LÉON, 2002, p. 143-145.

22 PAULILO, 2003.

${ }^{23}$ DESER, 2000.

${ }^{24}$ Informações baseadas na pesquisa "Avaliação dos impactos sócio-econômicos da previdência rural", realizada em 1998, sob a coordenação do IPEA, com a execução, na região Sul, pelo DESER e pelo IPARDES. Foram realizadas 3.000 entrevistas com aposentados/as e pensionistas rurais, sorteados/as aleatoriamente em 150 municípios dos três estados do Sul.

${ }^{25}$ Essa situação é comum também em inúmeras regiões do Brasil. Ver, entre outros, Margarida MOURA, 1978.

${ }^{26}$ Informações baseadas na pesquisa "Avaliação dos impactos sócio-econômicos da previdência rural", mencionada na nota 24.
} 
Em algumas regiões ainda se usa a palavra 'dote' para o que é dado às moças por ocasião do casamento. Ineke van Halsema ${ }^{27}$ faz considerações interessantes sobre o uso desse termo, dizendo que 'dote' tradicionalmente significa uma forma de herança prémortem dada às mulheres para lhes garantir segurança, status e independência na relação marital, e isso dificilmente aplicar-se-ia ao que foi visto nas regiões em estudo, tanto dela quanto nossa.

O fato de filhos e filhas não receberem terra quando saem da casa dos pais para estudar ou trabalhar na cidade, caso em que não permanecem trabalhando na propriedade, leva a pensarmos na partilha da terra mais como uma forma de remuneração do esforço investido na manutenção e aumento do patrimônio que como herança. Halsema encontrou inclusive a expressão 'ganhar sua parte', no sentido de ter trabalhado para merecê-la, e isso não acontece só com os rapazes. Exemplifica com casos em que a jovem sai para trabalhar recebendo salário e, então, ela mesma compra seu enxoval, pois não se fez jus à sua parte trabalhando nos campos. Assim, a frase dita pelas mulheres sobre "terem trabalhado tanto quanto seus irmãos" faz sentido. Faz sentido também atentarmos para a discriminação que é não considerar as lidas femininas, na casa ou na roça, como 'trabalho'. A desvalorização das múltiplas tarefas femininas nas estatísticas oficiais - daí a expressão 'trabalho invisível' - é um reflexo da desvalorização que perpassa toda a sociedade e suas principais instituições, incluindo a família.

Nesse ponto, reencontramo-nos com nosso objetivo de discutir o trabalho familiar. Na verdade, essa forma de trabalho afeta tanto homens como mulheres e não está restrita às atividades agrícolas, porém nossa ênfase recai sobre as agricultoras. Com relação aos rapazes, vale a pena fazer pelo menos uma consideração. O/os sucessor/es só poderá/ão assumir a responsabilidade pela exploração agrícola quando o pai ou se retira da atividade ou morre. A aposentadoria não significa parar de trabalhar, mas receber todo mês um pequeno montante de dinheiro bastante apreciado. Com a longevidade aumentando cada vez mais, os que trabalham junto à família ficam na posição de dependentes por longo tempo. Muitas vezes é esta a causa da saída dos filhos da propriedade e não a precária situação econômica. Porém, como no Brasil há sempre a imagem de que a chamada 'pequena agricultura' é inviável, tornava-se automático atribuir toda saída do campo para a cidade a fatores econômicos e dar-lhe sempre o rótulo de 'êxodo rural', mesmo que estudos mostrem que é a profissão de agricultor, entre todas, que apresenta o maior número de filhos seguindo as atividades dos pais. Valmir Stropazolas ${ }^{28}$ analisa essa questão com profundidade em sua pesquisa sobre juventude rural.

A sucessão masculina e tardia não é um problema só brasileiro, nem só da América Latina. Cada vez está se tornando mais urgente que se crie um estatuto para a produção familiar através do qual a esposa e os filhos maiores de 18 anos tenham direito a participar das decisões e da renda. A rigor, a esposa teria esse direito no Brasil, mas é prática corrente, por exemplo, os bancos exigirem só a assinatura do marido para qualquer financiamento e, mesmo quando é a mulher a dona da terra, a assinatura só dela não basta.

A tradicional exclusão feminina do acesso à terra faz com que elas também sejam ignoradas pelas políticas públicas voltadas para a agricultura familiar, por mais que as leis brasileiras condenem a discriminação por sexo. Andréa Butto, assessora especial do Ministério do Desenvolvimento Agrário para a área de Ações Afirmativas, afirma que, entre 1996 e 2002, o Programa Nacional de Agricultura Familiar (PRONAF) teve entre seus

\footnotetext{
27 HALSEMA, 1991.

${ }^{28}$ STROPASOLAS, 2002.
} 
beneficiários/as apenas $7 \%$ de mulheres. ${ }^{29}$ No ano de 1996, as mulheres representaram $12,6 \%$ do total dos beneficiários do Programa Nacional de Reforma Agrária (PNRA). Ainda segundo a mesma autora, pesquisa da FAO/UNICAMP, em 2002, revela que foram para os homens $87 \%$ dos títulos distribuídos pelo Instituto Nacional de Colonização e Reforma Agrária (INCRA) e 93\% das terras do programa Cédula da Terra. Do total dos beneficiados pelo programa de aquisição de terras Cédula da Terra e Crédito Fundiário, apenas 7\% eram mulheres. Para a coordenadora da Comissão Nacional de Mulheres Trabalhadoras Rurais da Confederação Nacional dos Trabalhadores na Agricultura (CONTAG), Raimunda C. de Mascena, ${ }^{30}$ a Medida Provisória $n^{\circ} .121$, de maio de 2001, que instituiu a cota mínima de $30 \%$ dos recursos destinados aos projetos e programas a serem distribuídos preferencialmente às mulheres, não provocou nenhum impacto na prática. Como ouvimos em um encontro de mulheres rurais: "e quem vai vigiar os bancos?".

A exclusão das mulheres não pára por aí, atingindo também a previdência rural. Dados do Departamento de Estudos Sócio-Econômicos e Rurais da Central Única dos Trabalhadores (DESER/CUT) mostram que, ${ }^{31}$ enquanto para os homens existe um excluído da aposentadoria por idade para cada 47,3 já aposentados, entre as mulheres essa proporção é de uma não-aposentada para cada 14,4 aposentadas. Além disso, há um homem inválido excluído da aposentadoria por invalidez para 3,2 aposentados e uma mulher excluída para 1,4 aposentada.

Embora a legislação preveja um máximo de 45 dias para que sejam concedidos os benefícios e o tempo médio, incluindo os benefícios urbanos, seja de 20 dias; para os rurais, $81 \%$ das concessões demoram mais de um mês. A maioria $(53,1 \%)$ dos beneficiários rurais teve de esperar entre 2 e 6 meses, e 18,9\% esperou mais de um ano. As mulheres são um pouco mais discriminadas que os homens na espera da concessão, pois $20,8 \%$ recebem o benefício no mínimo depois de um ano de entrada do requerimento, o que ocorre com 10,9\% dos homens. Como os homens estão familiarizados há mais tempo com o sistema de concessões de benefícios através do antigo Fundo de Assistência ao Trabalhador Rural (FUNRURAL), encontram menos problemas que as mulheres durante 0 processo. Enquanto $28,8 \%$ dos homens afirmaram ter tido problemas, essa porcentagem se eleva para $39,5 \%$ no caso das mulheres.

A luta por direitos previdenciários iguais está presente nas reivindicações dos movimentos de mulheres rurais, mas a exclusão da terra é quase um tabu, não aparecendo como uma bandeira de luta forte em nenhum dos movimentos.

\section{Mulher rural e movimentos sociais}

Para escrevermos este item nos inspiramos no trabalho de Carmen Deere e Magdalena Léon - O empoderamento da mulher -, que nos foi de grande valia. As autoras colocaram em palavras claras o que sentíamos de maneira difusa, ${ }^{32}$ ou seja, que os movimentos feministas na América Latina, nos últimos anos, têm dado mais importância às questões de identidade e reconhecimento, com ênfase nos direitos reprodutivos e fim da violência contra as mulheres, que às questões relativas aos direitos de propriedade e redistribuição de renda. A exemplo delas, nossa intenção neste artigo é trazer essas questões de volta, tentando mostrar que é difícil falar em reconhecimento sem estabelecer uma ligação com qualquer forma de suporte financeiro.

${ }^{29}$ BUTTO, 2003.

${ }^{30}$ MASCENA, 2003, p. 6.

${ }^{31}$ Informações baseadas na pesquisa "Avaliação dos impactos sócio-econômicos da previdência rural".

${ }^{32}$ DEERE e LÉON, 2002, p. 37. 
Deere e León não são as únicas autoras a sentir falta, dentro do movimento feminista, de uma postura mais enfática com relação à posição econômica desigual da mulher. 0 direito de tomar decisões sobre a própria vida depende de uma certa retaguarda financeira. Viviana Zelizer, ${ }^{33}$ ao discutir o sentido social do dinheiro, põe em questão a imagem abstrata que lhe é atribuída, negando sua incondicional intercambialidade. Para demonstrar suas idéias, investiga a distribuição do orçamento doméstico, especialmente o montante que é considerado 'dinheiro da mulher', nos Estados Unidos, entre os anos 1870 e 1930. Diz que, apesar da grande importância que têm as discussões sobre como deve ser usado o dinheiro na desarmonia entre casais e pais e filhos, pouca atenção é dada a esse fato. Afirma que a distribuição da renda entre os membros da família é freqüentemente tão desigual e arbitrária quanto a distribuição da renda nacional entre as famílias. Mostra, em sua pesquisa, que as mulheres que não tinham renda própria, freqüentemente, eram obrigadas a negociar com o marido cada dispêndio, usando estratégias que passavam pela adulação, favores sexuais, apresentação de gastos fictícios ou aumento no preço real dos bens e serviços, roubo puro e simples, entre outras estratégias, todas elas implicando submissão ou risco. As que trabalhavam fora, em geral, tinham seu dinheiro controlado pelo marido e investiamno coletivamente, em itens que beneficiassem a família toda. Sabemos o quanto essa situação permanece até hoje.

Os primeiros estudos feministas nas Ciências Sociais receberam o nome de Sociologia e/ou antropologia 'da mulher'. Porém, o texto bastante conhecido da historiadora Joan Scott no qual ela faz considerações sobre a importância da categoria 'gênero' como instrumento de análise tornou rapidamente obsoleto o uso da primeira denominação. Nas palavras da autora, "o gênero é um elemento constitutivo de relações sociais fundadas sobre as diferenças percebidas entre os sexos, e o gênero é um primeiro modo de dar significado às relações de poder". ${ }^{34}$

Apesar da quase unanimidade sobre a importância de se usar a categoria 'gênero' em vez de 'mulher', ${ }^{35}$ concordamos com Claudia de Lima Costa, quando ela diz que a adoção do conceito de gênero por parte dos Estados e das agências intergovernamentais nas Américas fez com que a crítica feminista à opressão e à subordinação da mulher tenha se diluído e sido neutralizada nos discursos e nas práticas dessas instituições. Daí a autora conclui que "o gênero enquanto categoria permitiu uma certa despolitização dos estudos feministas na academia latino-americana". ${ }^{36}$ As autoras Pamela Abbott e Claire Wallace $^{37}$ fazem uma crítica contundente ao conceito de gênero e insistem que uma Sociologia feminista deve ser feita "para as mulheres" e não "sobre as mulheres". Embora não concordemos com a radicalidade da crítica dessas duas autoras, concordamos que é preciso quebrar uma certa unanimidade, principalmente acadêmica, em torno do conceito de gênero.

Mesmo a historiadora feminista Joan Scott, que é uma das mais reconhecidas teóricas do conceito de gênero e em nada refratária às contribuições pós-modernas, afirmou que uma desconstrução sem fim das idéias não oferece suporte para programas de ação que

\footnotetext{
33 ZELIZER, 1989.

${ }^{34}$ SCOTT, 1990, p. 14.

${ }^{35}$ CADERNOS PAGU, 1998, e CRÍTICA MARXISTA, 2000.

${ }^{36}$ COSTA, 1998, p. 129.

${ }^{37}$ ABBOTT e WALLACE, 1997.
} 
busquem minorar as desigualdades. ${ }^{38}$ Para ela, a desconstrução é uma arma de luta enquanto nos permite mostrar as raízes machistas de muitas das idéias consagradas. Outra autora feminista, Janice Maclaughlin, afirma que o feminismo é um contribuinte ativo e não um receptor passivo do pós-modenismo. ${ }^{39}$

É interessante notar que durante uma oficina denominada "Gênero, classe e socialismo", realizada durante o III Fórum Social Mundial, ocorrido em Porto Alegre/RS, nos dias 23 a 27 de janeiro de 2003, e organizada pelo Movimento de Mulheres Trabalhadoras Rurais do Brasil e pela Via Campesina, também surgiram críticas ao conceito de gênero, como a que foi colocada por Gina Benitez, da Colômbia, quando diz que "la política neoliberal há tomado también la perspectiva de gênero y le há dado outra manera [...] Uribe [...] ha puesto una mujer de Ministra de Defensa, que dirije el derramamiento de sangre del pueblo".

Se por um lado muito das críticas ao conceito de gênero está baseado em uma forte postura marxista que teme que o conceito de classe acabe por se diluir entre inúmeras diferenciações - gênero, etnia, raça, religião e outras -, muito da aceitação deriva de uma concordância implícita de que os conceitos de 'mulher' e 'gênero' se equivalem, tanto assim que, quando o título de uma publicação, conferência ou congresso inclui a palavra 'gênero', podemos ter certeza de que se vai estar falando de mulher. Porém, essa não é apenas uma questão semântica, porque construções diferentes levam à criação de identidades diferentes entre os movimentos de mulheres. Essas identidades unem um grupo de mulheres mas, por serem normativas, afastam outros grupos. Os atritos que observamos entre diferentes movimentos de mulheres, embora possam parecer superficiais e haver um esforço, talvez inconsciente, para que assim sejam vistos, têm raízes profundas nas concepções de classe e gênero que possuem. Como não há concepções neutras, Deere e Léon ${ }^{40}$ falam que uma concepção praticável de equidade de gênero deve envolver uma pluralidade de princípios normativos. Nesse sentido, uma maior explicitação dos princípios que regem a noção de igualdade em diferentes contextos contribuiria para ampliar o diálogo entre os movimentos de mulheres e entre eles e outros movimentos.

O sociólogo português Boaventura de Souza Santos, em sua fala sobre multiculturalismo durante o já citado III Fórum Social Mundial, diz bem que a identidade é uma maneira que temos de nos dar sentido e que o diálogo multicultural é difícil porque há coisas que não se quer compartilhar quando não se tem confiança, confiança que não pôde ser desenvolvida em séculos de desencontros e discriminações. O diálogo só será possível quando cada cultura tiver consciência de sua incompletude, em vez de se atribuir um papel colonizador. Sobre igualdade e diferença, afirma que queremos "direito igual quando nos inferiorizam, direito diferente quando nos descaracterizam".

Com base nas palavras de Boaventura de Souza Santos, podemos dizer que também os movimentos de mulheres conseguirão dialogar melhor quando cada um tiver clareza de sua incompletude e não se considerar o responsável pela 'luta principal'.

\footnotetext{
38 'Although deconstruction has been labeled 'nihilistic' and 'deconstructive' by its critics, these epithets seem to me to be substitutes for serious evaluation of its possibilities. It may be that some deconstructive critics pursue an endless exposure of contradiction and are thereby unable to endorse or comfortably advocate a political program of their own. But there are also evident examples of a political empowerment by this approach, politics that are not only critical of existing social hierarchy but able to point out the premises of their operations; politics that are self-consciuosly critical of their own justification and exclusion, and so refuse an absolutist or totalizing stance" (SCOTT, 1988, p. 9).

39 "Feminism is the active contributor to, not the passive receiver of, post-modernism" (MCLAUGHLIN, 1997, p. 8).

${ }^{40}$ DEERE e LÉON, 2002, p. 51.
} 
A idéia de que não se deve 'dividir a luta' faz com que se fale da existência de diferentes movimentos de mulheres rurais como algo a ser superado e, mais que isso, falase como se a junção deles só dependesse de esclarecimentos e boa vontade, já que as diferenças seriam superficiais. Nossa hipótese é outra; é a de que as diferenças são profundas e de que valeria a pena se perguntar se conviver com um maior pluralismo não seria mais importante para diminuir as desigualdades de gênero do que investir esforços em uma unificação. ${ }^{41}$

Pesquisamos ${ }^{42}$ três tipos de movimentos de mulheres rurais: movimentos autônomos, ${ }^{43}$ movimento sindical e movimento de mulheres ligadas ao Movimento dos Trabalhadores Rurais Sem Terra (MST), nos três estados do Sul do Brasil: Paraná, Santa Catarina e Rio Grande do Sul. Tínhamos como dois de nossos objetivos a) ver como se dá a hierarquização das questões de classe e gênero em diferentes movimentos no campo, buscando perceber quais as representações que legitimam a postura adotada; e b) procurar identificar os pontos mais fortes de consenso e os de ruptura entre esses movimentos.

Com relação ao primeiro objetivo, reforçamos a idéia de que há diferenças significativas entre os movimentos. Enquanto o MST e os sindicatos enfatizam as questões de classe, sendo as mulheres parte dessa classe, os movimentos autônomos se dedicam mais às questões de gênero, no sentido de dar prioridade ao que preocupa as mulheres no seu dia-a-dia. A palavra 'gênero' aparece no discurso das militantes dos vários movimentos com grande facilidade, facilidade que certamente diminuiria se houvesse maior clareza de quantas concepções diferentes estão se abrigando sob um mesmo conceito. Como diz Scott, ${ }^{44}$ enquanto em uma postura objetivista classe e gênero são vistos como fenômenos naturais que aparecem juntos na história das idéias, encará-los como representações faz com que se separem, na medida em que uma concepção machista do mundo está embutida na construção do que são o trabalho, os direitos trabalhistas e até mesmo os direitos humanos. $O$ 'sujeito universal' é masculino. Ao estudarmos a importância que cada movimento dá à articulação entre classe e gênero, percebemos que suas representações sobre os dois fenômenos não se juntam facilmente, de tal maneira que se torna bastante difícil partir-se da discussão sobre um deles e, por acréscimo, aprofundar-se na discussão do outro, embora, no discurso, eles apareçam juntos. Isso só é possível pela grande elasticidade e pouca explicitação do que sejam 'questões de gênero'.

Nos movimentos que colocam a luta de classes em primeiro lugar, o modelo de participação política é machista. O discurso da igualdade de gênero é consenso, mas não se discute quão desigual é essa igualdade, na medida em que se cobra das mulheres

\footnotetext{
${ }^{41}$ PAULILO, 2003.

${ }^{42}$ Agradecemos o apoio do CNPq e do convênio Plano Sul de Pesquisa/CNPq/FUNCITEC. O apoio conjunto do CNPq (Conselho Nacional de Pesquisa) e da FUNCITEC (Fundação de Ciência e Tecnologia) propiciou uma ampla pesquisa abrangendo os três estados do Sul do País e a presença em vários encontros de mulheres rurais. Isso nos permitiu gravar tanto as falas 'oficiais' da/os palestrantes convidadas/os, como as entrevistas que realizamos com as participantes, utilizando um total de cerca de 80 fitas. Nesse trabalho tivemos a colaboração inestimável dos bolsistas Elaine Müllher, Valdete Boni, Edenilse Pellegrini, Sirlei Aparecida Fernandes e Marco Aurélio Loch, aos quais manifestamos nosso profundo reconhecimento.

${ }^{43}$ São chamados de movimentos autônomos de mulheres porque não recebem apoio financeiro estável de nenhuma instituição ou outro movimento. Nacionalmente eles se agrupam sob a sigla Movimento de Mulheres Trabalhadoras Rurais (MMTR), que, em Santa Catarina, conservou o nome de Movimento de Mulheres Agricultoras (MMA). Como durante a pesquisa estivemos muito próximos do movimento catarinense, a sigla MMA será mais usada neste texto que MMTR. Segundo informações de militantes, o MMTR está mudando seu nome para Movimento de Mulheres Camponesas (MMC).

${ }^{44}$ SCOTT, 1988, p. 63-64.
} 
um comportamento masculino e elas acabam por incorporá-lo, sentindo-se culpadas quando não conseguem segui-lo à risca. Também esses movimentos tendem a criticar os movimentos autônomos de mulheres por considerá-los como radicais e separatistas. Nas entrevistas com líderes femininas do MST, coerentes com sua concepção de igualdade de gênero, elas consideram sem importância a pergunta de quantos homens e quantas mulheres participam de cargos de direção e, muitas vezes, preferem não respondê-la, pois "que importância tem isso?". Quando participam como palestrantes em reuniões só de mulheres, ressaltam sempre a ligação entre as diferenças de gênero e as de classe, no sentido de que, ao se aperceber da primeira, adultos e crianças se aperceberão da segunda. Porém, há muito mais homens que mulheres nos cargos de direção no MST. Mesmo nos dois assentamentos de reforma agrária totalmente coletivos que conhecemos, os homens participam com oito horas diárias de trabalho nos campos e as mulheres com quatro, por causa do trabalho doméstico pouco dividido com os homens.

Pelo fato de a última Constituição, promulgada em 1988, possibilitar à mulher rural o estatuto de 'produtoras rurais' $e$, com isso, dar-lhe acesso aos direitos trabalhistas, o número de mulheres sindicalizadas aumentou significativamente na última década, já que são os sindicatos que trazem esclarecimentos e ajuda burocrática. Mas, como constatamos em outra pesquisa, ${ }^{45}$ a sindicalização não significou necessariamente politização.

Valdete Boni ${ }^{46}$ estudou o Sindicato dos Trabalhadores Rurais (STR) de Chapecó e região, que congrega cinco municípios e que foi conquistado pelas oposições sindicais, ligadas à igreja católica progressista e aos movimentos sociais, em 1982. Uma das primeiras medidas da nova direção foi promover campanhas para a sindicalização e a documentação das mulheres, pois muitas não tinham nem mesmo carteiras de identidade. Outra preocupação foi que os nomes das esposas constassem do Bloco do Produtor, documento onde são registradas as transações comerciais da propriedade agrícola, para que elas, provando ser produtoras rurais, tivessem acesso aos direitos trabalhistas como aposentadoria, licença-maternidade e auxílio-doença. Porém, segundo a autora, "mesmo as mulheres ocupando a presidência do sindicato, isto não significa que estes tenham mudado totalmente suas práticas discriminatórias". ${ }^{47}$ A dificuldade em preencher a cota de $30 \%$ de mulheres nas direções sindicais, estabelecida pela Central única dos Trabalhadores (CUT), é atribuída menos ao pouco reconhecimento que a capacidade e o trabalho das mulheres encontram nesse ambiente, que à pouca iniciativa das mulheres. Ao reproduzir algumas das falas das mulheres dirigentes, Valdete Boni mostra que mesmo quando elas admitem que, "por a gente ser mulher, os outros acham que a gente não tem capacidade de administrar e de estar envolvido", também dizem que "a própria mulher não desafia para enfrentar uma liderança". ${ }^{48}$

Um dos argumentos mais utilizados para criticar os movimentos autônomos de mulheres é que esse comportamento 'divide a luta', o que mostra que para os sindicatos e o MST existe só 'a' luta, ou uma luta principal e não muitas. Aqui temos uma longa discussão que inclui também movimentos como os dos negros, homossexuais, índios e outros. Essa discussão se junta às polêmicas em torno da idéia de identidade. Para as feministas consideradas essencialistas, as mulheres têm algo em comum pelo simples fato de serem mulheres. Para as críticas dessa postura, como Chantal Mouffe, ${ }^{49}$ "a desconstrução das

\footnotetext{
45 PAULILO, Marineide SILVA e Alessandra DE GRANDI, 2003.

${ }^{46}$ BONI, 2002.

47 BONI, 2002, p. 2.

${ }^{48}$ BONI, 2002, p. 11.

${ }^{49}$ MOUFFE, 1996, p. 104.
} 
identidades essenciais deve ser vista como condição necessária para a compreensão adequada da diversidade das relações sociais a que os princípios da liberdade e da igualdade devem aplicar-se".

Do ponto de vista da criação de identidades demasiado fixas, se os movimentos autônomos de mulheres podem ser criticados por enfatizar a condição feminina, a mesma crítica pode ser feita aos outros dois movimentos por priorizarem a questão de classe. A criação de identidades coletivas é importante para que um grupo leve avante ações conjuntas, mas a abertura para dialogar com grupos que constroem de outra forma sua identidade permite a existência de sociedades mais democráticas.

Os movimentos autônomos de mulheres são vistos pelas sindicalistas apenas como uma etapa para que as mulheres se preparem para uma militância nos espaços públicos já existentes, como sindicatos, prefeituras e partidos, e não como tendo objetivos próprios. Como diz uma dirigente sindical entrevistada por Valdete Boni, o MMA "é um espaço onde a mulher passa a sair de casa, participar... e a partir daí, lógico, que as mulheres não podem ficar específico no MMA, têm que ir ocupando outros espaços". ${ }^{50}$

Para militantes antigas dos movimentos autônomos de mulheres, não é tão 'lógico' assim que tenham que ir para outros espaços. Apesar das críticas que recebem das sindicalistas e do MST por não fazerem discussões conjuntas com os homens, as militantes dos movimentos autônomos continuam a fazer seus encontros com uma insignificante participação masculina, como pudemos observar participando de três grandes encontros e outros menores. Preferem conversar 'entre mulheres', pois consideram a presença masculina inibidora. Reclamam que nas reuniões mistas, quando podem falar, nem sempre são ouvidas, e que um certo menosprezo muitas vezes carregado de ironia as constrange. No espaço que é só delas podem falar livremente das desigualdades que lhes são mais cotidianas, as que se reproduzem dentro do grupo familiar, sem que isso seja considerado 'bobagem', 'falta de assunto sério' ou 'choradeira geral', porque é comum as mulheres se emocionarem ao exporem, quase sempre pela primeira vez, suas angústias e vê-las compartilhadas. Os membros dos sindicatos e do MST se opõem a grupos que não lhes são próximos afetivamente e podem ser considerados como 'inimigos', o que não acontece com as mulheres, seus maridos, pais, sogros, irmãos e filhos homens.

Com o segundo objetivo nós nos preocupávamos em identificar os pontos de consenso e os de ruptura entre os movimentos de mulheres. Ao entrevistarmos uma líder nacional do MST, ela assim caracterizou os movimentos de mulheres segundo suas metas principais: mulheres do MST: reforma agrária; mulheres dos sindicatos: agricultura familiar; e movimentos autônomos de mulheres: saúde. Nossas entrevistas confirmaram essa classificação. Veja-se que os objetivos dos dois primeiros grupos são comuns a homens e mulheres, enquanto a saúde sempre foi considerada 'assunto de mulher'. Mas há pelo menos um ponto comum aos movimentos: todos eles discutem questões ligadas à visibilidade da mulher e à necessidade de se imporem como produtoras rurais, não mais colocando no lugar da profissão, em documentos oficiais, a expressão 'do lar', como sempre havia sido o costume. Porém, a expressão 'produtora rural' é atribuída com grande naturalidade apenas às mulheres casadas ou viúvas. As solteiras, ou ainda vão casar, ou vão arrumar emprego. O mais perto que as mulheres estão chegando com relação à questão do acesso à terra é buscar titulação conjunta da propriedade e ter o nome no Bloco do Produtor. Quando insistimos na exclusão das filhas da herança da terra, muitas dizem que isso já está mudando, mas é muito difícil conseguir um exemplo concreto.

${ }^{50}$ BONI, 2002, p. 10. 
Uma diferença importante entre os movimentos é a forma de organização. As mulheres que pertencem aos sindicatos se encontram dentro de uma estrutura formalizada em nível nacional. Se, por um lado, elas têm espaço garantido através das cotas e verbas próprias, há certa rigidez na hora da ação, porque as decisões devem ser aprovadas em várias instâncias. As mais feministas procuram canalizar alguns esforços para discussões e ações ligadas às questões de gênero, mas não é fácil, segundo elas, conseguir tempo e recursos. O MST, por seu lado, possui uma estrutura bastante centralizada e procura promover a igualdade entre homens e mulheres fazendo com que estas estejam presentes em todos os tipos de comissões e instâncias. Os militantes reconhecem a participação majoritária masculina, mas atribuem isso ao fato de que é preciso mais tempo para mudar costumes antigos. As entrevistadas desse movimento não mostraram simpatia por ações afirmativas como sistema de cotas, o que acontece também com algumas dirigentes sindicais.

Os movimentos autônomos de mulheres têm uma organização bem mais fluida e menos hierárquica, havendo uma preocupação maior com as especificidade locais, o que pode ser visto até na conservação dos nomes originais. Embora exista uma organização nacional conhecida como Movimento de Mulheres Trabalhadoras Rurais (MMTR) e assim ele seja conhecido também no Rio Grande do Sul, em Santa Catarina o movimento conserva a sua primeira denominação - Movimento de Mulheres Rurais (MMA) - e no Paraná temos Organização de Mulheres Rurais (OMTR). Como suas decisões não precisam alcançar uma unanimidade nacional, essas mulheres têm muita facilidade para se mobilizarem rapidamente. Quando se marcam reuniões nos municípios, vão poucas pessoas, mas quando se trata de reivindicar medidas voltadas para a educação e a saúde conseguese grande número de participantes nas marchas e atos públicos. A deputada federal Luci Choinacki, ao nos contar a mobilização havida em Brasília por ocasião da regulamentação do auxílio-maternidade para as mulheres rurais, disse que só com a grande participação dos movimentos autônomos foi possível juntar três mil mulheres na Capital Federal.

Dos três movimentos estudados, o que se mostra mais propenso a problematizar as desigualdades domésticas é o MMA. Para os outros dois movimentos, a questão está resolvida pelo menos teoricamente: se somos todos iguais, todos têm que fazer de tudo. É só uma questão de tempo e boa vontade as mulheres 'aprenderem' a fazer política e os homens 'se conformarem' em dividir as tarefas domésticas. Não entra em questão a divisão trabalho doméstico/trabalho produtivo, que é o que queremos discutir no próximo item.

\section{Trabalho doméstico \& Trabalho produtivo}

René Descartes, em sua famosa obra, escrita em 1637, Discurso sobre o método, estabelece como sendo o segundo princípio de seu método "dividir cada dificuldade a ser examinada em tantas partes quanto possível e necessário para resolvê-las". ${ }^{51}$ Esse princípio levou à divisão disciplinar das ciências, enquanto o terceiro princípio, que recomenda a ordenação dos assuntos em uma escala que vai dos mais simples aos mais complexos, levou a uma busca da 'pedra fundamental' do conhecimento que, para os positivistas lógicos da Escola de Viena, principalmente para seu fundador Moritz Schilick, seria o conceito mais próximo do empírico, o que partia do 'dado', podendo ser apreendido pelos sentidos. ${ }^{52} \mathrm{O}$ conhecimento deveria ir, através da indução, do particular para o geral. O complexo, então, era subdivido em partes e organizado em uma escala que ia do mais facilmente acessível ao mais distante do conhecimento imediato. Maior vitória conseguia

${ }^{51}$ DESCARTES, 1975, p. 27-28.

52 SCHILICK, 1975. 
sobre a ignorância quem fosse capaz de reduzir o problema à escala mais singela que é a dicotômica. Nesse raciocínio se encaixam as polarizações 'comunidade/sociedade', 'rural/urbano', 'tradicional/moderno' e outras.

Para José de Souza Martins, ${ }^{53}$ não é só uma fidelidade à epistemologia cartesiana que faz a Sociologia ter no seu cerne pares de idéias-elementos opostas, correspondentes à antítese conservadorismo/racionalismo, a saber: comunidade/sociedade; autoridade/ poder; status/classe; sagrado/profano; e alienação/progresso. Para ele, isso é conseqüência do que chama de "ambigüidade fundamental da Sociologia", que, dito em poucas palavras, significa o fato de essa disciplina ter surgido de uma reação conservadora ao racionalismo oitocentista e não de sua evolução. Recupera, então, idéias ligadas à ordem feudal mas sem poder manter seu sentido original. A Sociologia propõe-se a explicar a sociedade capitalista com noções que lhe são estranhas, daí sua ambigüidade que acaba por se refletir na Sociologia rural, que, para compreender o campo, simplifica-o a ponto de torná-lo irreconhecível. Ou seja, essa ambigüidade tende a se resolver, na prática, procurando transformar o rural que existe e, no âmbito do conhecimento, "desdobra-se nas dicotomias, de tal modo que em cada termo da dicotomia não haja ambigüidade e que na interpretação da vida social o mundo é que pareça ambíguo". ${ }^{54}$

Quando Terry Marsden e seus colaboradores ${ }^{55}$ dizem que há uma necessidade urgente de deslocar os estudos rurais das margens das Ciências Sociais para seu centro para dar conta da importância contemporânea dos espaços rurais, concordamos com a primeira parte da afirmação dos autores, mas não inteiramente com a segunda. Concordamos que é preciso reconduzir os estudos rurais para o centro das preocupações sociológicas, mas não somente por causa da atual relevância dos espaços agropastoris, mas sim porque os estudos rurais, e a própria conceituação do que é 'campo', em oposição à 'cidade', se originam no momento mesmo do nascimento da Sociologia. Aparecem nas margens apenas pela tentativa do pensamento moderno de simplificar o mundo, colocando-o em uma escala evolucionista que vai do rural ao urbano. Seja pelas correntes de pensamento liberal, seja por aquelas de pensamento marxista, até que a modernidade começasse a ser questionada, o mundo foi pensado por uma ótica progressista centrada na produção e no mercado, sendo a sociedade urbano-industrial uma meta a ser alcançada, ou por ser um fim em si mesma, ou por ser uma etapa necessária para uma nova era.

Enquanto a família existiu como unidade de produção, as mulheres e as crianças participavam diretamente das atividades consideradas econômicas. O aparecimento do capitalismo, segundo Heleieth Saffioti, ${ }^{56}$ se dá em condições adversas à mulher porque a encontrou já em uma situação social tradicional de subordinação e de desvalorização de seu trabalho, o que a tornou presa fácil dos baixos salários, das longas jornadas e da prioridade por ocasião de dispensa de trabalhadores. Como historicamente já vinha ela desempenhando o papel de principal responsável pela casa e pelos filhos, o lar foi se tornando seu espaço por excelência, a ponto de a sociedade passar a só admitir seu afastamento do papel de esposa e mãe em casos de necessidade financeira.

O capitalismo fez mais do que separar os meios de produção do trabalho e o espaço doméstico do espaço de produção. Foi a primeira vez na história que se tentou subordinar a sociedade ao mercado. Os princípios da antiga ordem social foram substituídos pelo

\footnotetext{
${ }^{53}$ MARTINS, 1981.

${ }^{54}$ MARTINS, 1981, p. 23.

${ }^{55}$ MARSDEN et al., 1992, p. 2.

${ }^{56}$ SAFFIOTI, 1976.
} 
princípio da permuta ou troca, cujo padrão subjacente era o padrão de mercado. ${ }^{57} \mathrm{E}$ assim o único esforço físico ou mental que passou a merecer o nome de trabalho produtivo e a ser remunerado foi o despendido nas atividades consideradas econômicas. Daí a separação entre trabalho produtivo e não produtivo, nada fácil de se visualizar quando não há separação entre unidade familiar e de produção, como é o caso do campesinato. Quando a mulher faz queijo, por exemplo, pode fazê-lo para comer ou vender.

A ênfase dada ao econômico foi tão forte que o movimento feminista, na tentativa de mostrar a importância do trabalho doméstico, procurou vê-lo do ponto de vista do quanto ele contribuía para o capital, na medida em que a esposa desdobrava o baixo salário do marido através de longas jornadas de trabalho não pagas em casa. Com isso, propunha-se que ele fosse considerado uma atividade econômica e, portanto, trabalho produtivo.

Embora concordemos com esse caráter econômico do trabalho doméstico, como não dar importância à esfera da reprodução? Sem novas gerações, a sociedade humana desapareceria. Nancy Folbre ${ }^{58}$ diz que as crianças que nascem não são apenas uma garantia de sustento para seus pais, mas para a sociedade toda. Quando adultos, são elas que vão produzir, pagar impostos, ter filhos e gerar o excedente necessário para sustentar as novas crianças e os idosos. Filhos bem criados, com saúde e educação adequada, são um bem para toda a sociedade, mas uma responsabilidade quase exclusiva das mães. Segundo Folbre, enquanto a reciprocidade entre marido e mulher, por ser algo que acontece no presente, pode ser mais controlada e o casamento é um contrato que pode ser desfeito, a reciprocidade entre pais se filhos se dá em termos de futuro. Quem se dedica aos filhos sabe quanto Ihes dá mas não pode saber quanto irá receber, nem se seus descendentes sobreviverão, terão saúde ou conseguirão emprego, ou seja, estarão aptos a retribuir.

Por ter que arcar com a maior parte dos ônus da reprodução, as mulheres têm menores possibilidades de conseguir bons empregos ou ascender na carreira profissional que seus maridos. Não é difícil entender por que, entre os pobres do mundo, os mais pobres são as mulheres. Dados oficiais apresentados na Segunda Conferência da ONU sobre a Mulher, realizada em Copenhagen em 1980, mostram as mulheres como cerca da metade da população mundial, um terço da força de trabalho oficial e responsáveis por dois terços do trabalho realizado, mas sendo beneficiárias de apenas um décimo da renda produtiva e de $1 \%$ da propriedade mundial. ${ }^{59}$ Dada a dificuldade de se obter esse tipo de informação, a probabilidade de que esses dados estejam subestimados é alta e, mesmo assim, são alarmantes. No Brasil, segundo o Instituto de Economia do Rio de Janeiro, no ano de 2000 , do total de pessoas sem acesso à renda monetária, $80 \%$ eram mulheres trabalhadoras rurais. ${ }^{60}$ Dados do CEPAL mostram que na América Latina a pobreza extrema é mais rural que urbana. Embora dos 204 milhões de pobres apenas 78 milhões vivam no meio rural, se nos concentrarmos na população indigente, $60 \%$ dela é rural. $O$ índice de feminilidade da pobreza mostra um número maior de mulheres que de homens pobres nas zonas rurais da Bolívia, Brasil, Colômbia, Costa Rica, Chile e Paraguai, atingindo seu índice máximo na República Dominicana, com 115 mulheres pobres para cada 100 homens na mesma condição. ${ }^{61}$

\footnotetext{
${ }^{57}$ POLANYI, 1980.

${ }^{58}$ FOLBRE, 2001.

${ }^{59}$ DEERE e LÉON, 2002, p. 28.

${ }^{60}$ BUTTO, 2003.

${ }^{61}$ RICO $~$ D DIRVEN, 2003.
} 
Nas propriedades familiares rurais não é nada simples separar o que é trabalho doméstico do que seria trabalho produtivo. Afinal, o conceito de 'trabalho produtivo' foi cunhado para situações em que se dá a extração da mais-valia, ou seja, quando o trabalho excedente é apropriado pelo dono dos meios de produção, ou seja, o capitalista. Querer empobrecer seu sentido até reduzi-lo ao trabalho que produz o que pode ser vendido, 0 que tem valor de troca, é, como diz Alexander Chayanov, tentar explicar diferentes formas de produzir apenas com categorias adequadas para o modo de produção capitalista, 0 que só faz sentido se entendermos essas formas com transitórias, em vias de extinção. ${ }^{62}$ São muitos os que hoje acreditam que a agricultura familiar terá espaço no futuro tanto dos países desenvolvidos como no dos em desenvolvimento.

Ao estudarmos o trabalho das mulheres rurais em cinco regiões diferentes do Brasil, em épocas diferentes, ${ }^{63}$ percebemos que a distinção entre trabalho 'pesado' feito pelos homens e trabalho 'leve' feito pelas mulheres não se devia a uma qualidade do próprio esforço despendido mas ao sexo de quem o executava, de tal modo que qualquer trabalho era considerado leve se feito por mulheres, por mais exaustivo, desgastante ou prejudicial à saúde que fosse. Vemos o mesmo fenômeno se repetir quando da divisão entre trabalho doméstico e trabalho produtivo. É simples: é doméstico se é atribuição da mulher. Se ela vai para a roça com o marido, é trabalho produtivo, mesmo que o que for colhido seja tanto para vender como para comer. Se cuida da horta e das galinhas sozinha, é trabalho doméstico. Se vende ovos de vez em quando, uma galinha ou outra, é tão pouco que não vale a pena teorizar sobre isso. Mesmo nos assentamentos de reforma agrária coletivos com os quais tivemos contato, onde tanta desigualdade foi questionada, ainda se diz que "os homens trabalham oito horas e as mulheres quatro, por causa do serviço de casa".

Embora exista no Brasil a agricultura familiar enquanto tipo de empreendimento econômico, não existe a categoria profissional 'trabalhador familiar'. ${ }^{64}$ Nas estatísticas, com exceção do homem, considerado como responsável pela exploração, a esposa e os filhos aparecem como 'membros não remunerados da família', embora o pai também não seja remunerado. Talvez seja um reconhecimento implícito de que ele é quem tem maior poder sobre a renda familiar. Os sindicatos são Sindicatos de Trabalhadores Rurais, o conjunto dos movimentos autônomos de mulheres é chamado de Movimento de Mulheres Trabalhadoras Rurais. Depois de muita luta, as mulheres casadas conseguiram o estatuto de 'produtoras rurais', o que lhes garantiu direitos trabalhistas. Mas que direitos têm filhos e filhas que trabalharam desde pequenos na propriedade dos pais? Embora não seja comum, um filho ou filha pode requerer seus direitos de herança em juízo, mas nada pode fazer se

${ }^{62}$ CHAYANOV, 1981.

${ }^{63}$ PAULILO, 1987 e 1996.

${ }^{64}$ Essa questão se torna mais clara através do parecer elaborado, em 12 de julho de 2002, pelo advogado Arni Deonildo Hall, assessor jurídico da Federação dos Trabalhadores na Agricultura Familiar da Região Sul (FETRAF-SUL), relativo à possibilidade de caracterização dos agricultores familiares como categoria profissional específica, diversa da categoria genérica de trabalhadores rurais, para fins de enquadramento sindical, no caso, Sindicato dos Trabalhadores da Agricultura Familiar. Segundo o autor, em função inclusive das próprias lutas dos agricultores familiares, em 1996, através do Decreto 1946/96, surge o Programa Nacional de Fortalecimento da Agricultura Familiar (PRONAF). Com a instituição desse programa aparece, pela primeira vez, de forma clara, no ordenamento jurídico brasileiro, um texto legal referente à 'agricultura familiar'. Em seguida, o Banco Central caracterizou esse tipo de agricultor (Resolução 2191/96, art. $2^{\circ}$ ) para poder regulamentar a utilização dos recursos públicos disponibilizados para o PRONAF. Porém, se o Estado brasileiro reconhece a agricultura familiar para fins de políticas públicas, os 'trabalhadores da agricultura familiar' continuam profissionalmente enquadrados na categoria 'trabalhadores rurais'. Essa situação permanece até o momento em que este artigo está sendo escrito, início de abril de 2004. 
seu pai quiser se desfazer da terra ainda em vida. Entre os muitos arranjos para desobedecer ao Código Civil, que exige herança igualitária para todos os filhos, vendas e compras fictícias de propriedades são comuns no meio rural no Sul do Brasil. Também é o pai que detém a renda. Assim, como garantir uma distribuição mais justa para esposa e filhas, quando o trabalho das mulheres é tão desvalorizado? Embora, segundo o Censo Agropecuário 1995/96, os agricultores familiares representem $85,2 \%$ do total de estabelecimentos agrícolas do país, ${ }^{65}$ não há no nosso direito um estatuto que ampare 0 trabalhador familiar.

Diante desses problemas certamente dolorosos para quem os vivencia no dia-adia, as soluções apresentadas são também dolorosas. Quanto à oposição, falsa a meu ver, entre trabalho doméstico e trabalho produtivo, propõe-se que todos façam de tudo, querendo ou não, gostando ou não. A grande maravilha dos questionamentos sobre a existência do 'instinto materno', a começar por Sexo e temperamento, de Margareth Mead, ${ }^{66}$ foi possibilitar às mulheres não se considerarem seres anormais ou culpáveis quando não se sentiam predispostas à maternidade. O feminismo levou esses questionamentos muito mais adiante. Não cremos que seria um grande avanço nos sentirmos todos, mulheres e homens, culpados por não termos vontade de 'fazer de tudo'. Igualdade e liberdade dificilmente andam juntas, mas pode-se fazer um esforço para conseguir um ajuste melhor. Se a divisão entre esfera doméstica e produtiva fosse rompida e todos os trabalhos fossem igualmente valorizados, ficaria mais fácil deixar que cada casal fizesse suas próprias negociações levando em conta vontades e aptidões.

No caso das propostas coletivas mais radicais, a idéia é que tudo deveria ser socializado: refeições, filhos, lavação de roupa, etc., o que, por ser um tanto difícil de ser implementado, é sempre adiado. A não-participação igualitária dos homens no trabalho doméstico é tão pouco levada a sério que é sempre admitida sem pejo e com risos. Em visita que fizemos a Cuba, em 1991, os homens, brincando, diziam que eram 'machistasleninistas' em vez de 'marxistas-leninistas'. Penso que os homens solteiros que moram sozinhos riem menos quando, para não fazerem esse serviço, têm que pagar a lavadeira, a faxineira, comer em restaurantes ou preparar sua própria comida.

Quanto ao fato de que a divisão de tarefas remete à relação esposa/marido e pais/filhos, a recomendação um tanto singela é que é preciso 'se impor', o que implica desgaste emocional, afetivo e até mesmo físico. Pesquisa realizada em 2002 pelo Movimento de Mulheres Agricultoras com 550 agricultoras, em 15 municípios do estado de Santa Catarina, ${ }^{67}$ revela que $14,91 \%$ das entrevistadas já foram espancadas, sendo que $8,73 \%$ o foram pelo marido ou namorado. Que esse número está subestimado pode ser visto pelo fato de que, das entrevistadas, $48,36 \%$ conhecem alguma mulher na sua comunidade que já foi espancada e $26,18 \%$ não quiseram responder se sofreram ou não algum tipo de violência. Além disso, 64,18\% dizem não ter liberdade de tomar decisões sem pedir licença ao marido, $19,82 \%$ dizem poder fazê-lo poucas vezes e $52,0 \%$ normalmente tomam qualquer decisão apenas com a concordância do marido. Quanto às filhas e filhos, Stropazolas ${ }^{68}$ mostra que a obediência aos pais é exigida e respeitada.

Com esses dados não estamos querendo colocar o rural novamente como o lugar do 'rude', do 'atrasado', em oposição ao 'urbano', de onde preconceituosamente derivou o termo 'urbanidade' como sinônimo de 'polidez' ou 'gentileza'. Essa mesma pesquisa

\footnotetext{
${ }^{65}$ INCRA/FAO, 2000.

${ }^{66}$ MEAD, 1935.

${ }^{67}$ MMA, 2002.

${ }^{68}$ STROPASOLAS, 2002.
} 
mostrou que 34,0\% das agricultoras entrevistadas, embora saiam pouco de seu meio, já foram humilhadas com expressões como 'colona grossa', ${ }^{69}$ 'burra', 'relaxada' e outras. A violência doméstica não respeita região nem classe social, mas sabemos que ela aumenta quanto menos opção tem a mulher para manter-se financeiramente longe de um marido violento. Se as mulheres rurais estão marginalizadas do acesso à terra e à renda e se a condição de celibatária não é nada invejável, elas estão mais sujeitas a condições adversas no casamento.

\section{Considerações finais}

Na era moderna, a idéia de 'civilização' foi identificada com valores urbano-industriais. O 'rural' não foi algo preexistente, mas algo construído no mesmo momento em que se separou campo e cidade. Ele é tão fruto da modernidade quanto as chaminés das fábricas. A Sociologia, enquanto uma disciplina que surgiu no bojo do pensamento conservador, procura pensar o capitalismo com categorias estranhas a ele. Enquanto Karl Marx, um crítico desse modo de produção, falava em contradições de classe e sua superação, Émile Durkheim, considerado o pai da Sociologia, pensava a mudança social evolutiva em termos da passagem de uma solidariedade mecânica para uma solidariedade orgânica, em que cabiam conflitos mas não contradições. Se para Marx as diferenças eram pensadas em termos de desigualdade, para Durkheim eram pensadas em termos de diversidade. A oposição 'comunidade/sociedade' surge no bojo desse pensamento conservador e evolucionista, marcando uma dicotomia que se pensava seria superada historicamente. Já que isso não aconteceu espontaneamente, surgiu uma linha da Sociologia, denominada 'Sociologia Rural', cuja finalidade, como diz José de Souza Martins, ${ }^{70}$ era fazer com que seu objeto - o rural - desaparesse. Mas esse ramo da Sociologia acaba por engendrar sua própria crítica, e entre os sociólogos rurais surgem grandes teóricos da desigualdade.

O pensamento marxista sempre foi fonte de inspiração para os que consideravam a sociedade moderna injusta. Mas suas categorias de análise, cunhadas para o modo capitalista de produção, nunca foram de fácil apropriação por quem queria estudar o meio rural. O pensador russo Alexander Chayanov, inclusive, tentou fazer uma teoria para os sistemas não capitalistas de produção, que ficou inacabada. As soluções dadas foram muitas, mas tinham algo em comum. Como diz Teodor Shanin, ${ }^{71}$ tudo que não encontrasse espaço definido no modelo adotado era visto como 'articulado' ao modo dominante, que era o capitalista, tendo sido a palavra 'articulação' um termo-chave para resolver impasses. Porém, essa saída um tanto fácil acabou por se esgotar, principalmente porque a dialética acabava desaparecendo de um processo em quee tudo contribuía para o bem do capital.

A década de 1980 trouxe uma explosão do que se chamou de 'movimentos sociais', e a Sociologia começou a preocupar-se menos exclusivamente com a estrutura e dar mais importância à ação. Houve uma flexibilização dos esquemas teóricos. Dois outros grandes movimentos surgidos anteriormente, o feminismo e o movimento ambientalista, já tinham provocado novas teorizações. O pós-estruturalismo e o pós-modernismo levaram ainda muito mais longe a crítica às grandes teorias.

Estudando diferentes movimentos de mulheres rurais no Sul do Brasil, confirmamos nossa hipótese inicial de que as diferenças entre esses movimentos são profundas, pois

\footnotetext{
69 'Colona' significa agricultora descendente de italianos e alemães no Sul do Brasil, em uma relação com o termo 'colônia', que significava tanto o tamanho da propriedade destinada aos imigrantes quanto a localidade onde moravam.

${ }^{70}$ MARTINS, 1981.

7 SHANIN, 1980.
} 
derivam de representações diferentes do que seja 'igualdade de gênero', expressão que, dada sua grande aceitação, está encobrindo conflitos cuja eclosão se faz na forma de divergências pessoais, de alegação de falta de tempo para tantas questões, de briga por espaço por parte das lideranças, enfim, na forma de divergências contornáveis com alguma boa vontade e amadurecimento. Essa maneira de encarar os conflitos encobre sua dimensão. O que está em jogo é se a convicção, presente entre as militantes de todos os movimentos, de que as questões de gênero podem ser incorporadas simplesmente por acréscimo às questões de classe é viável. Mesmo as militantes dos movimentos autônomos, que são as que mais se dedicam às questões de gênero ligadas ao cotidiano, pensam que a relação com os outros dois movimentos depende mais deles que delas, pois pensam que eles as marginalizam, no que parecem ter certa razão, pois as sindicalistas e as militantes do MST convivem com os movimentos autônomos até o ponto que os encaram como uma etapa de suas próprias lutas. Para as sindicalistas, reunindo-se, elas se preparam para entrar no espaço público; para o MST, ao discutir a desigualdade de gênero dentro do grupo familiar e tentar superá-la, as mulheres estariam se preparando para entender outras desigualdades e tentar superá-las também.

Quanto às mulheres dos movimentos autônomos, se perguntadas sobre os outros movimentos, elas os consideram importantes, mas não se sentem bem representadas por eles e nem motivadas a integrá-los. Dizem que as mulheres têm 'seu próprio jeito de lutar'. Esse jeito é considerado menos competitivo, mais coletivo e mais ligado ao cotidiano. Para quem critica o 'jeito feminino', esse é o jeito que a mulher 'aprendeu a ser'. Não resta dúvida sobre isso, mas o modelo masculino de luta também é o jeito que os homens aprenderam a ser. Por que, então, tomar o masculino como sendo o correto?

Apesar de a construção da igualdade passar pela idéia de que 'todos devem fazer de tudo', as mulheres são muito cobradas se não conseguem 'se impor', se não 'se desafiam', enquanto o fato de os homens não dividirem o trabalho doméstico é um pecado menor, tão leve que risível. Essa igualdade, a nosso ver, masculina, torna vã inclusive a pergunta sobre quantos são os homens e quantas são as mulheres que participam dos cargos de direção nos movimentos mistos. Não é sem razão que uma pesquisa sobre violência doméstica partiu do MMA e não dos outros dois movimentos.

$\mathrm{O}$ acesso à terra e à renda é nitidamente desigual entre homens e mulheres, e isso é muito pouco discutido nos três movimentos estudados, embora nenhuma militante negue tal realidade quando perguntada. As mais otimistas dizem que a situação já está mudando. Os dados são menos alvissareiros. Apesar de a frase "trabalhei tanto quanto meus irmãos na terra de meus pais" ser uma expressão comum de ressentimento por parte das mulheres por não terem recebido terra quando da partilha da propriedade, nenhuma deixou de utilizar o termo 'herança' para denominar a divisão da propriedade depois da morte dos pais. Em nenhum momento falou-se da partilha como forma de 'pagamento por serviços prestados'. A impressão que se tem é que a palavra 'herança', já consagrada, cria uma espécie de obstáculo para que se entenda o processo de outra forma. Cremos que um estatuto da pequena produção que garantisse distribuição de renda igualitária para esposo e esposa e proporcional a filhos maiores, sem distinção de sexo, tornará sem sentido a separação entre trabalho doméstico e trabalho produtivo e assim as jovens saberiam que seu trabalho vale tanto quanto $o$ do seus irmãos na manutenção do patrimônio e na reprodução da família. Se as filhas e filhos não são proprietários da terra, também não podem ser considerados apenas empregados e pagos como tal; são sócios mesmo que minoritários do empreendimento, pois comprometem seu futuro mantendo, quando não aumentando, esse patrimônio. 
Os movimentos estudados fizeram uma campanha vitoriosa para que as mulheres obtivessem documentos tais como carteira de identidade e título de eleitor. Continuam insistindo, já com bem menos sucesso, para que façam seus nomes constarem do Bloco do Produtor e que procurem ter seus nomes no título de propriedade da terra. Porém, não há insistência para que tenham sua própria conta no banco; no máximo há a insitência de que a tenham em conjunto com o marido. Persiste a idéia de que a renda é familiar, o que pressupõe distribuição igualitária entre seus membros. Permanece intocada a imagem da família rural como um todo coeso, tão cara aos órgãos de extensão rural e às igrejas, grandes incentivadoras dos movimentos sociais no campo. A quase totalidade das militantes iniciaram sua trajetória junto a grupos religiosos, principalmente ligados à igreja católica.

Sobre a categoria 'gênero', embora seja quase impossível discordar da conceituação a ela dada por Joan Scott, acreditamos que é preciso romper com a aparente tranqüilidade teórica que seu conteúdo relacional transmite, pois, para os movimentos socais, seu uso (e abuso) está sendo um obstáculo para se pensar diferenças importantes. Ninguém discorda de que não existe uma questão feminina que não seja também masculina, ou melhor, que não seja da sociedade toda. Mas se nem a sociedade toda, nem todos os movimentos de mulheres e nem as famílias isoladamente estão dispostos a levantar bandeiras de luta que toquem em pontos tão cruciais como a distribuição da terra e da renda no meio rural, fica difícil continuar utilizando um conceito tão genérico. O problema não está na construção teórica do conceito, mas na sua apropriação pelos movimentos sociais rurais. Admitir que um problema é resultado de uma relação e ter como corolário pensar que, por isso, sua superação só poderá ocorrer se houver concordância entre as partes é ter uma confiança excessiva e não justificada na magnanimidade dos privilegiados em abrir mão de seus privilégios. Tem havido, nas últimas décadas, uma grande ênfase na eficácia da participação popular nas esferas de decisão. Parte significativa dos pensadores marxistas abriu mão de uma idéia de revolução para a defesa de uma democracia participativa, mas também se sabe que falar e ser ouvido são coisas diferentes. Participação implica também, ou melhor, quase sempre, enfrentamentos.

O medo de 'dividir a luta', derivado da idéia de que existe uma única luta que vale a pena e de que ela tem dono, leva a desencontros entre os diferentes movimentos de mulheres dependendo da ênfase que dão a questões de classe ou gênero. Esses desencontros, porém, são minimizados através de um conceito amplo de 'igualdade de gênero' em que cabem muitas desigualdades. O diálogo, então, torna-se mais difícil porque, na prática, a aparente homogeneidade dos chavões se desfaz, e o que era 'diferença' aparece como 'dissidência', dando lugar a recriminações e ressentimentos. Não poderíamos pensar que, ao invés de dividir, a existência de várias frentes de confronto pluraliza a luta, enriquecendo- $a$ ?

\section{Referências bibliográficas}

ABBOT, Pamela, and WALLACE, Claire. An Introduction to Sociology: Feminist Perspectives. London and New York: Routledge, 1997.

ABRAMOVAY, Ricardo. Paradigmas do capitalismo agrário em questão. São Paulo; Rio de Janeiro; Campinas: HUCITEC; ANPOCS, UNICAMP, 1992.

ABREU, Alice Rangel de Paiva. "Processo de trabalho e ciências sociais: a contribuição do GT 'Processo de Trabalho e Reivindicações Sociais'”. In: ENCONTRO ANUAL DA ANPOCS, 9, 1985, Águas de São Pedro, SP. Anais... São Pedro, 1985.

ARAÚJO, Maria Paula. "A questão camponesa na teoria marxista clássica". In: CHEVITARESE (Org.). O campesinato na história. Rio de Janeiro: Relume Dumará, 2002. p. 65-74. 
BIRNBAUM, Pierre; CHAZEL, François (Orgs.). Teoria sociológica. São Paulo: HUCITEC-EDUSP, 1977.

BONI, Valdete. "Poder e igualdade: as relações de gênero entre sindicalistas rurais Chapecó/SC". In: CONGRESSO DA ASSOCIAÇÃO LATINO-AMERICANA DE SOCIOLOGIA RURAL, 6, 25 a 29 nov. 2002, Porto Alegre. Anais... Mimeo.

BUTTO, Andréa. "A perspectiva de gênero nos programas de desenvolvimento rural e combate à pobreza no Brasil: políticas públicas". In: SEMINÁRIO "GÊNERO Y ENFOQUE TERRITORIAL DEL DESARROLLO RURAL", 14 a 17 jul. 2003, Natal. Anais... Natal, 2003.

CADERNOS PAGU. Campinas: UNICAMP, n. 11, Feminismo(s) contemporâneo(s), 1998.

CARDOSO, Ciro F. "Camponês, campesinato: questões acadêmicas, questões políticas". In: CHEVITARESE, A. L. (Org.). O campesinato na história. Rio de Janeiro: Relume Dumará: FAPERJ, 2002. p.19-38.

CHAYANOY, Alexander. Sobre a teoria dos sistemas econômicos não capitalistas. In: SILVA, José Grasiano da; STOLCKE, Verena (Orgs.). A questão agrária. São Paulo: Brasilense, 1981. p. 133-163.

CHEVITARESE, A. L. (Org.). O campesinato na história. Rio de Janeiro: Relume Dumará: FAPERJ, 2002.

COSTA, Claudia de Lima. "O tráfico do gênero". Cadernos Pagu, n. 11, p. 127-140, 1998.

CRÍTICA MARXISTA. São Paulo: Boitempo Editorial, n. 11, 2000.

DEERE, Carmen D.; LEÓN, Magdalena. O empoderamento da mulher. Porto Alegre: Ed. da UFRGS, 2002.

DESCARTES, René. Discurso sobre o método. São Paulo: HEMUS, 1975.

DESER (Departamento Sindical de Estudos Rurais). Perspectivas de vida e trabalho da juventude rural na região Sul. Curitiba, 2000. Mimeo.

FOLBRE, Nancy. The Production of People by Means of People and the Distribuition of the Costs of Children. Paper presented at IUSSP Seminar on International Perspecyives on Low Fertility: Trends, Theories and Policy. Tókio, Japão, 21-23 March 2001.

GASSON, Ruth, and ERINGTON, Andrew. The Farm Family Business. Wallington: CAB International, 1993.

HALSEMA, Ineke van. Housewives in the Field: Power, Culture and Gender in a South-Brazilian village. Amsterdam: CEDLA, 1991.

INCRA/FAO (Instituto Nacional de Colonização e Reforma Agrária/Organização das Nações Unidas para Agricultura e Alimentação). O novo retrato da agricultura familiar: o Brasil redescoberto. Brasília: Projeto de Colaboração Técnica INCRA/FAO, 2000.

MARSDEN, Terry et al. Constructing the Countryside. London: UCL, 1992.

MARTINS, José de Souza. "As coisas no lugar: da ambigüidade à dualidade na reflexão sociológica sobre a relação cidade-campo". In: MARTINS, José de Souza (Org.). Introdução crítica à sociologia rural. São Paulo: Hucitec, 1981.

MASCENA, Raimunda C. de. "A perspectiva de gênero nos programas de desenvolvimento rural sustentável e combate à pobreza no Brasil: políticas públicas. In: SEMINÁRIO "GÊNERO Y ENFOQUE TERRITORIAL DEL DESARROLLO RURAL", 14 a 17 jul. 2003 Natal. Anais... Natal, 2003.

MCLAUGHLIN, Janice. "Feminist Relation with Post-Modernism: Reflexions on the Positive Aspects of Envolviment." Journal of Gender Studies, v. 6, n. 1, 1997. p. 5-15.

MEAD, Margareth. Sex and temperament. New York: Ed. Mentor, 1935.

MOUFFE, Chantal. "Feminismo, cidadania e política democrática radical". O regresso do político. Lisboa: Gradiva, 1996. p. 101-120. 
MMA (MOVIMENTO DE MULHERES AGRICULTORAS). Dados revelam: a face oculta da violência contra as mulheres agricultoras. Documento apresentado no seminário "Dia Latinoamericano de Combate à Violência contra a Mulher". Chapecó, SC, 2002. Mimeo.

MOURA, Margarida. Os herdeiros da terra. São Paulo: Hucitec, 1978.

MURDOCK, Jonathan, and PRATT, Andy. "Rural Studies: Modernism, Post-Modernism and the 'Post-Rural'." Journal of Rural Studies, v. 9, n. 4, 1993. p. 411-427.

PAULILO, Maria Ignez. "O peso do trabalho leve". Revista Ciência Hoje. Rio de Janeiro: SBPC, v. 5, n. 28, p. 64-70, 1987.

. "The Burden of the Light Work: the Devaluation of Women's Work in Brazilian Agriculture." Cadernos de Pesquisa, Florianópolis: PPGSP/UFSC, n. 7, 1996.

. "Movimento de mulheres agricultoras: terra e matrimônio". In: PAULILO, Maria Ignez; SCHMIDT, Wilson. Agricultura e espaço rural em Santa Catarina. Florianópolis: Ed. da UFSC, 2003. p. 183-210.

PAULILO, Maria Ignez; SILVA, Marineide M.; DE GRANDI, Alessandra B. "Mulher e atividade leiteira: a dupla face da exclusão". In: PAULILO, Maria Ignez; SCHMIDT, Wilson. Agricultura e espaço rural em Santa Catarina. Florianópolis: Ed. da UFSC, 2003. p. 15-38.

POLANYI, Karl. A grande transformação. Rio de Janeiro: Campus, 1980.

RICO, Maria Nieves; DIRVEN, Martine. "Aproximaciones hacia um desarrollo rural territorial com enfoque de gênero". In: SEMINÁRIO "GÉNERO Y ENFOQUE TERRITORIAL DEL DESARROLLO RURAL", 14 a 17 de jul. 2003, Natal. Anais... Natal, 2003.

SAFFIOTI, Heleieth I. B. A mulher na sociedade de classes: mito e realidade. Petrópolis: Vozes, 1976.

SCHILICK, Moritz. "Positivismo e realismo". In: POPPER, Karl; SCHLICK, Moritz; CARNAP, Rudolf. Popper/Schlick/Carnap. São Paulo: Abril, 1975. (Os pensadores, v. XLIV, p. 45. 70).

SCHMALENBACH, Herman. "Comunidade e liga". In: BIRNBAUM, Pierre; CHAZEL, François (Orgs.). Teoria sociológica. São Paulo: HUCITEC-EDUSP, 1977. p. 117-119.

SHANIN, Teodor. "A definição de camponês: conceituações e desconceituações". Estudos CEBRAP, Rio de Janeiro: Vozes, n. 26, p. 41-80, 1980.

SCOT, Joan W. Gender and the Politics of History. New York: Columbia University Press, 1988. . "Gênero: uma categoria útil de análise histórica". Educação e Realidade, Porto Alegre, v, 16, n. 2, p. 5-22, 1990.

SOIHET, Rachel. "Como a imprensa ridicularizava a luta feminista". Revista Nossa História, São Paulo: Fundação Biblioteca Nacional, ano 1, n. 3, p. 14-20, jan. 2004.

STROPASOLAS, Valmir Luiz. O mundo rural no horizonte dos jovens: o caso dos filhos(as) de agricultores familiares de Ouro/SC. 2002. Tese (Doutorado Interdisciplinar em Ciências Humanas) - Universidade Federal de Santa Catarina, Florianópolis.

TEPICHT, Jerzy. Marxisme et agriculture: le paysan polonais. Paris: Armand Colin, 1973.

TÖNNIES, Ferdinand. "Comunidade e sociedade". In: BIRNBAUM, Pierre; CHAZEL, François (Orgs.). Teoria sociológica. São Paulo: HUCITEC-EDUSP, 1977. p. 106-114.

VARDI, Liana. "Imagining the Haverst in Early Modern Europe." In: SCOTT, James C., and BHATT, Nina. Agrarian Studies. New Haven and London: Yale University Press, 2001 . p. 86138.

WEBER, Max. Sobre a teoria das ciências sociais. Lisboa: Editorial Presenta; São Paulo: Martins Fontes, 1977a.

. Economía y sociedad. Mexico - Bogota: Fondo de Cultura Económica, 1977b.

WILKINSON, John. O Estado, a agroindústria e a pequena produção. São Paulo; Salvador: HUCITEC; CEPA/BA, 1986.

ZELIZER, Viviana A. "The Social Meaning of Money: 'Special Monies'." American Journal of Sociology, v. 95, n. 2, Sept. 1989. p. 342-377. 


\section{Family Work: a Forgotten Category of Analysis}

Abstract: The influence of Marxism on Labor Sociology and Feminism was and still is very strong. This has led to an emphasis on working class studies. Questions concerning the peasantry became difficult to work with within Marxism and Feminism. There used to be a general belief the liberation of women would necessarily require their financial independence, which would be the result of individual insertion in the labor market. This has raised the question of where to consider the role of women's work within the family. This issue was not adequately considered by theory that was frequently dominated by urban perspectives and that overlooked issues of the role of women in rural activities. The rise of various rural women's movements in Brazil has questioned the "victim" status normally attached to such women, to the degree that they have proved to be true social "actors". At this time, however, feminist movements are more concerned with issues of recognition and identity, then with income redistribution, property, and that which most interests us, land. The purpose of this paper is to unveil the prejudices permeating the analysis of peasantry and bring back the issue of the economic inequality of women involved in family agriculture, whose access to land is achieved almost exclusively through marriage. The right to take decisions about one's own life may not depend on an individual salary, but it certainly depends on access to one's own source of income.

Key words: social rural movements, gender, feminism, family farm. 